\title{
Abundance and Distribution of Medicinal Plants in Madapi Forest Kerinci Seblat National Park (KSNP) Rejang Lebong, Bengkulu
}

\author{
Guswarni Anwar, Oktariani, Agus Susatya, Putranto BAN, Wiryono \\ Department of Forestry, Faculty of Agriculture, University of Bengkulu, Indonesia \\ Correspondence author: ganwar@unib.ac.id
}

\begin{abstract}
Kerinci Seblat National Park (KSNP) as a conservation area posses a strategic role as a source of medicinal plants. This research on the potential of medicinal plants as one of Non-Timber Forest Products (NTFPs) in the MADAPI Forest in Rejang Lebong Region of KNSP, in Bengkulu Province, aimed to determine the species richness, abundance, and spatial distribution of medicinal plants in the forest. This research is important to find out the potential of KSNP in providing medicinal plants. Sampling of plants was conducted in 80 plots, each measuring 20x20m in four sections of MADAPI Forest. From 80 plots, 33 species of medicinal plants were found, representing 27 families. Mostly the plants were herbs and the most dominant families found in the sites were Asteraceae and Moraceae. Based on its relative abundance, all of medicinal plant species were categorized as rare with clumped distribution; only a few species were spread randomly or uniformly.
\end{abstract}

\section{Keywords: abundance, distribution, MADAPI Forest, medicinal plants}

\section{INTRODUCTION}

Kerinci Seblat National Park (KSNP) located in Sumatra is the largest national park in Southeast Asia, named as the ASEAN Heritage National Park. Since the park has a very high biodiversity of both flora and fauna, it is designated as a part of the Tropical Rainforest Heritage of Sumatra (TRHS) and as a world heritage site by the World Heritage Committee [1]. KSNP covers four provinces, namely West Sumatra Province (353,780ha), Jambi Province (422,190ha), Bengkulu Province (310,910ha), and South Sumatra Province $(281,120 \mathrm{ha})$ [2]. In Bengkulu Province, KNSP is spread in four districts namely Rejang Lebong, Lebong, North Bengkulu, and Muko-Muko. The MADAPI forest is located within the KNSP Rejang Lebong, Bengkulu which is composed of four main sections with three dominant tree species of KNSP namely Swietenia mahagoni (L). Jacq. (mahagony/mahoni in Indonesia), Agathis dammara (Lamb.) Rich.(resin tree/damar), Pinus merkusii Jungh. \& de Vriese (pine/pinus), and another species, i.e. Aleurites moluccana (L.) Willd. (candlenut/kemiri).

Recently, illegal exploitation of the KSNP conservation area, especially in Rejang Lebong District in the form of illegal logging and land encroachment for coffee plantations has increased intensively. This causes ecological damages that disrupt the strategic function of KSNP as carbon storage, oxygen provider, and regulator of water systems, primarily for the surrounding area. This illegal exploitation will also have an impact on the availability of medicinal plants [3]. According to Government Regulation No. 108/2015, a national park as a conservation area can have a certain zone which can be managed and utilized by the local community to get nontimber forest products (NTFPs) i.e. food plants, medicinal plants, latex, bamboo, rattan, and others [4]. Several studies identifying medicinal plants in national parks have been carried out, such as Fachrurozi [5] in the Gunung Gede National Park who found 45 species, and Zulnely et al [6] identified 20 species of medicinal plants in Mount Halimun Salak National Park. Research of medicinal plant diversity in KSNP has been carried out by Susatya [7] who found 16 families and 54 species that potential to be used as anti-cancer drugs, while 10 families and 37 species contained substances potential to be used against HIV.

This study was carried out to determine the species richness, abundance, and distribution of medicinal plants in MADAPI Forest. The data from this study will be useful for the conservation of existing NTFP species in KNSP.

\section{MATERIALS AND METHODS}

\subsection{Study area}

The study was carried out from April to October 2019 in MADAPI Forest Kerinci Seblat National Park Rejang Lebong, Bengkulu. The area located in Rejang Lebong District, approximately $100 \mathrm{~km}$ from Bengkulu City, the capital of Bengkulu Province, Indonesia, in the southern part of Sumatera region $\left(102^{\circ} 28^{\prime} 12^{\prime \prime}-102^{\circ} 29^{\prime} 24^{\prime \prime}\right.$ $\mathrm{E}$ and $03^{\circ} 21^{\prime} 00^{\prime \prime}-03^{\circ} 22^{\prime} 12^{\prime \prime} \mathrm{S}$ with altitudes ranging from 900 to $>1000 \mathrm{~m}$. The daily temperature varies from $16^{\circ} \mathrm{C}$ to $32^{\circ} \mathrm{C}$. The mean annual rainfall ranges from 1600 to $4000 \mathrm{~mm}$ per year. The MADAPI Forest area is 212.807 hectares which divided into four sections namely Swietenia mahagoni area (31.650ha), Agathis dammara (21.521ha), Pinus merkusii (148.796ha), and Aleurites moluccana ( (10.840 ha). The study site is shown in Figure 1. 


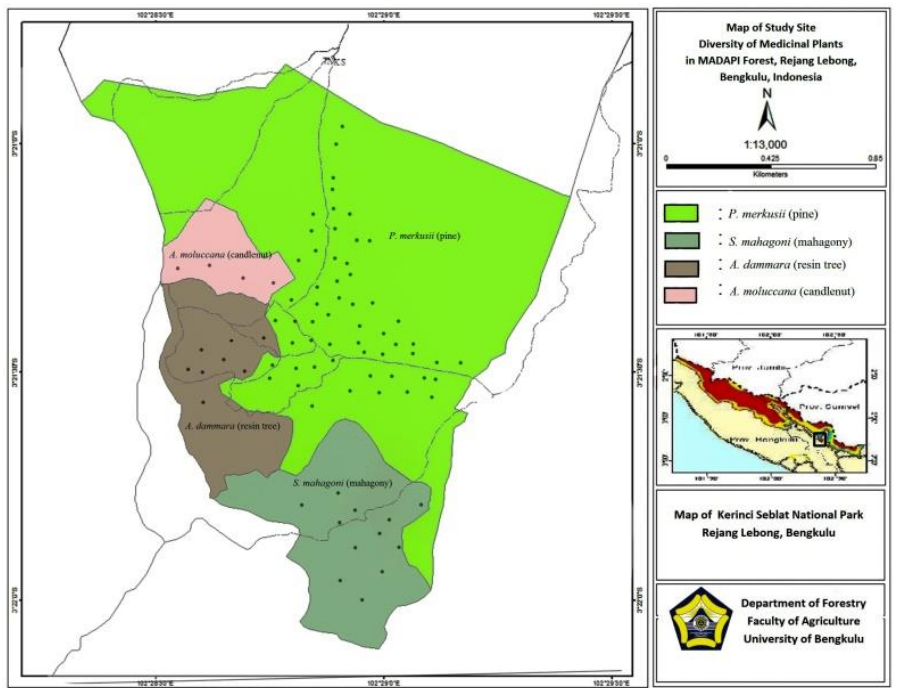

Figure 1. Plot distribution of the study site

\subsection{Procedures}

Sampling was conducted in four different sections with a total of 80 plots, each measuring $20 \times 20 \mathrm{~m}: S$. mahagoni (12 plots), A. dammara (8 plots), P. merkusii (56 plots), and A. moluccana (4 plots). Within each plot, the local names, number of individual plants, and life forms of each plant were recorded. Three local eguides who have good knowledge of the local medicinal plants assisted to identify the plants. The scientific names were identified by using books of the flora of Sumatera in the laboratory and some references on the internet. Herbarium specimens of some medicinal plants were collected in the laboratory.

\subsection{Data analysis}

Species abundance was determined using the formula of Mahajan and Fatima [8]) using the equation as following:

Density $=\frac{\text { total number of individual of the species }}{\text { total number of plot }}$

Relative Density $(\mathrm{RD})=\frac{\text { density of a given species }}{\text { total density of all the species }} \times 100 \%$

The abundance type is categorized as RD $1-20 \%$ : rare

RD 21-40\%: occasional

RD 41-60\%: frequent

RD 61-80\%: common

RD 81-100\%: abundant

Spatial distribution of the species was calculated by using Index of Dispersion (ID) or variance to mean ratio (VMR) [9]

$$
\text { Variance }=\frac{\Sigma \mathrm{f}(\mathrm{x}-\overline{\mathrm{x}}) 2}{\mathrm{~N}-1}
$$

Mean $=\Sigma \mathrm{f}(\mathrm{x}) / \mathrm{N}$

ID or VMR $=\frac{\text { Variance }}{\text { Mean }}$

where: $\mathrm{f}=$ observation plot
$\mathrm{X}=$ number of individual of a species

$\overline{\mathrm{x}}=$ sample mean

$\mathrm{N}=$ number of plot

If $\mathrm{VMR}<1$ : random distribution pattern

$\mathrm{VMR}=1$ : uniform distribution pattern

VMR $>1$ : clump distribution pattern

\section{RESULTS AND DISCUSSIONS}

\subsection{Species richness and abundance of medicinal plants}

Table 1 shows the species composition of the medicinal plants, their families, and life forms in the study sites. Asteraceae and Moraceae were the dominant families in all the sites. P. merkusii section had the highest number of individuals and A. moluccana section the least. Clidemia hirta was the most common species in P. merkusii stands (168), followed by Diplazium esculentum /ferns (92) and Erechtites valerianifolius (80). In the A. dammara section, the most dominant species was Clidemia hirta (63), followed by Diplazium esculentum (41) and Lantana camara (30). In the S. mahagoni area, it was dominated by Swietenia mahagoni (16) and Diplazium esculentum (68). In A. moluccana section was dominated by Diplazium esculentum (120), followed by Etlingera elatior (98) and A. moluccana (58). Some plants were found only in certain areas, such as A. moluccana, Psidium guajava, and Syzygium malaccensis were found in A. moluccana section; Alstonia scholaris and Artocarpus altilis in S. mahagoni section, and C. odorata and Ficus benjamina in the A. dammara section. The medicinal species that only found in the P. merkusii section was Andrographis paniculata, Asplenium nidus, Ceiba pentandra, Eurycoma longifolia, Ficus septica, and Trema orientalis. 
Table 1. Species composition of the medicinal plants at the study sites

\begin{tabular}{|c|c|c|c|c|c|c|c|c|c|}
\hline \multirow[b]{2}{*}{ \# } & \multirow[b]{2}{*}{ Species } & \multirow[b]{2}{*}{ Family } & \multirow[b]{2}{*}{$\begin{array}{l}\text { Local } \\
\text { Name }\end{array}$} & \multicolumn{4}{|c|}{$\begin{array}{l}\text { Number of the plant in the MADAPI } \\
\text { Forest sections }\end{array}$} & \multirow[b]{2}{*}{ Total } & \multirow[b]{2}{*}{ Lifeform } \\
\hline & & & & $\begin{array}{l}\text { S. maha } \\
\text { goni }\end{array}$ & $\begin{array}{l}\text { A. } \\
\text { dam } \\
\text { mara }\end{array}$ & $\begin{array}{l}\text { Pinus } \\
\text { merkusii }\end{array}$ & $\begin{array}{l}\text { A.moluc } \\
\text { cana }\end{array}$ & & \\
\hline 1 & $\begin{array}{l}\text { Ageratum conyzoides } \\
\text { L. }\end{array}$ & Asteracecae & Bandotan & - & 20 & 30 & - & 50 & Herb \\
\hline 2 & $\begin{array}{l}\text { Aleurites moluccana } \\
\text { (L.)Willd }\end{array}$ & Euphorbiaceae & Kemiri & - & - & - & 58 & 58 & Tree \\
\hline 3 & $\begin{array}{l}\text { Alstonia scholaris }(\mathrm{L}) \text {. } \\
\mathrm{R} \text {. Br. }\end{array}$ & Apocynaceae & Pulai & 1 & - & - & - & 1 & Tree \\
\hline 4 & $\begin{array}{l}\text { Alternanthera sessilis } \\
\text { (L.) R.Br. ex DC. }\end{array}$ & Amaranthacecae & Keremah & - & 11 & 7 & - & 18 & Herb \\
\hline 5 & $\begin{array}{l}\text { Andrographis } \\
\text { paniculata (Burm.f.) } \\
\text { Nees }\end{array}$ & Acanthaceae & Sambioloto & - & - & 2 & - & 2 & Herb \\
\hline 6 & $\begin{array}{l}\text { Artocarpus altilis } \\
\text { (Parkinson) Fosberg }\end{array}$ & Moraceace & Sukun & 3 & - & - & - & 3 & Tree \\
\hline 7 & Asplenium nidus L. & Aspleniaceae & $\begin{array}{l}\text { Paku sarang } \\
\text { burung }\end{array}$ & - & - & 3 & - & 3 & Herb \\
\hline 8 & Bambusa multiplex & Poacecae & Bambu & 4 & - & 18 & 1 & 23 & Shrub \\
\hline 9 & $\begin{array}{l}\text { Ceiba pentandra }(\mathrm{L} .) \\
\text { Guerto }\end{array}$ & Bombacaceae & Kapuk & - & - & 3 & - & 3 & Tree \\
\hline 10 & $\begin{array}{l}\text { Centella asiatica }(\mathrm{L} .) \\
\text { Urban }\end{array}$ & Apiaceae & Pegagan & - & - & 64 & - & 64 & Herb \\
\hline 11 & $\begin{array}{l}\text { Chromolaena odorata } \\
\text { (L.) R.M.King \& } \\
\text { H.Rob. }\end{array}$ & Asteraceae & Kirinyu & - & 20 & - & - & 20 & Herb \\
\hline 12 & $\begin{array}{l}\text { Clidemia hirta (L.) D. } \\
\text { Don }\end{array}$ & Melastomaceace & Keduruk & 3 & 63 & 168 & 13 & 247 & Shrub \\
\hline 13 & Coffea $\mathrm{sp}$ & Rubiaceae & Kopi & - & 20 & 63 & - & 83 & Shrub \\
\hline 14 & Curculigo latifolia & Hypoxidaceae & Singkut & - & - & 4 & - & 4 & Herb \\
\hline 15 & $\begin{array}{l}\text { Diplazium esculentum } \\
\text { (Retz.) Sw. }\end{array}$ & Athyriaceae & Pakis & 68 & 41 & 92 & 120 & 321 & Herb \\
\hline 16 & $\begin{array}{l}\text { Dracontomelon dao } \\
\text { (Blanco) Merr. \& Rolfe }\end{array}$ & Anacardiaceae & Sengkuang & 20 & - & - & - & 20 & Tree \\
\hline 17 & $\begin{array}{l}\text { Erechtites } \\
\text { valerianifolius }\end{array}$ & Asteracecae & Sintrong & 4 & 20 & 80 & 2 & 106 & Herb \\
\hline 18 & $\begin{array}{l}\text { Etlingera elatior (Jack) } \\
\text { R.M. Smith }\end{array}$ & Zingiberaceae & Kecombrang & - & - & - & 98 & 98 & Herb \\
\hline 19 & $\begin{array}{l}\text { Eurycoma longifolia } \\
\text { Jack }\end{array}$ & Simaroubaceae & Pasak Bumi & - & - & 2 & - & 2 & Shrub \\
\hline 20 & Ficus benjamina $\mathrm{L}$. & Moraceae & Beringin & - & 1 & - & - & 1 & Tree \\
\hline 21 & Ficus septica Burm. F. & Moraceae & Awar-awar & - & - & 4 & - & 4 & Tree \\
\hline 22 & Flagellaria indica $\mathrm{L}$. & Flagellariaceae & Rotan & 13 & 8 & 20 & - & 41 & Shrub \\
\hline 23 & $\begin{array}{l}\text { Homalomena cordata } \\
\text { Schott. }\end{array}$ & Aracecae & Keladi hutan & 5 & 4 & 10 & - & 19 & Herb \\
\hline 24 & $\begin{array}{l}\text { Imperata cylindrica } \\
\text { (L.) P.Beauv. }\end{array}$ & Poacecae & Alang-alang & 24 & 4 & 4 & - & 32 & Herb \\
\hline 25 & Lantana camara $\mathrm{L}$. & Verbenaceae & Tembelekan & - & 30 & 3 & - & 33 & Shrub \\
\hline 26 & $\begin{array}{l}\text { Melastoma } \\
\text { malabathricum } \mathrm{L} .\end{array}$ & Melastomaceace & Senduduk & - & - & 19 & - & 19 & Shrub \\
\hline 27 & Piper betle L. & Piperaceae & Sirih & 1 & 4 & 14 & 2 & 21 & Shrub \\
\hline 28 & Psidium guajava $\mathrm{L}$. & Myrtaceace & Jambu Biji & - & - & - & 1 & 1 & Tree \\
\hline 29 & $\begin{array}{l}\text { Pyrrosia piloselloides } \\
\text { (L.) M.G. Price }\end{array}$ & Polypodiaceae & Sisik naga & - & - & 4 & 5 & 9 & Herb \\
\hline 30 & Solanum torvum $\mathrm{Sw}$. & Solanaceace & Terang & 1 & 3 & 9 & - & 13 & Shrub \\
\hline 31 & $\begin{array}{l}\text { Swietenia mahagoni } \\
\text { (L.) Jacq. }\end{array}$ & Meliaceae & Mahoni & 167 & - & - & - & 167 & Tree \\
\hline 32 & $\begin{array}{l}\text { Syzygium malaccensis } \\
\text { (L.) Merr. \& Perry }\end{array}$ & Myrtaceae & Jambu Bol & - & - & - & 1 & 1 & Tree \\
\hline \multirow[t]{2}{*}{33} & $\begin{array}{l}\text { Trema orientalis }(\mathrm{L} .) \\
\text { Blume }\end{array}$ & Cannabaceae & Anggrung & - & - & 9 & - & 9 & Tree \\
\hline & TOTAL & & & 314 & 249 & 632 & 301 & 1496 & \\
\hline
\end{tabular}


Figure 2 displays the life form of medicinal plants. These results are the same as the findings in many other studies which also reported that medicinal plant species generally have habitus herbs, trees, and shrubs [10, 11, 12, 13].

There were 27 families of the medicinal plants found on the MADAPI Forest (Figure 3).. The most dominant family was Asteraceae (3 species), Moracecae ( 3 species), Poraceae and Myrtaceae were 2 species each. One species of Asteraceae, Chromolaena odorata was the most abundant. This species is common medicinal plants in Thailand and widely distributed in the tropics region [14]

Table 2 shows the abundance of medicinal plants from the each section. The most abundant species in the sites were $D$. esculentum and followed by $C$. hirta, $C$. odorata, S. mahagoni, E. valerianifolius, E. elatior, Coffea sp., C. asiatica, A. moluccana, and B. multiplex. However, all the species had an abundance percentage $<20 \%$ and categorized as rare.

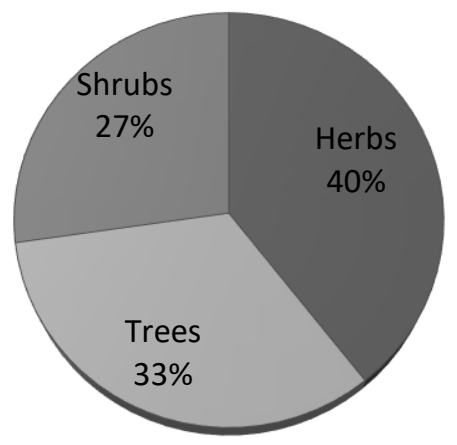

Figure 2. The life form of the medicinal plants in the MADAPI Forest

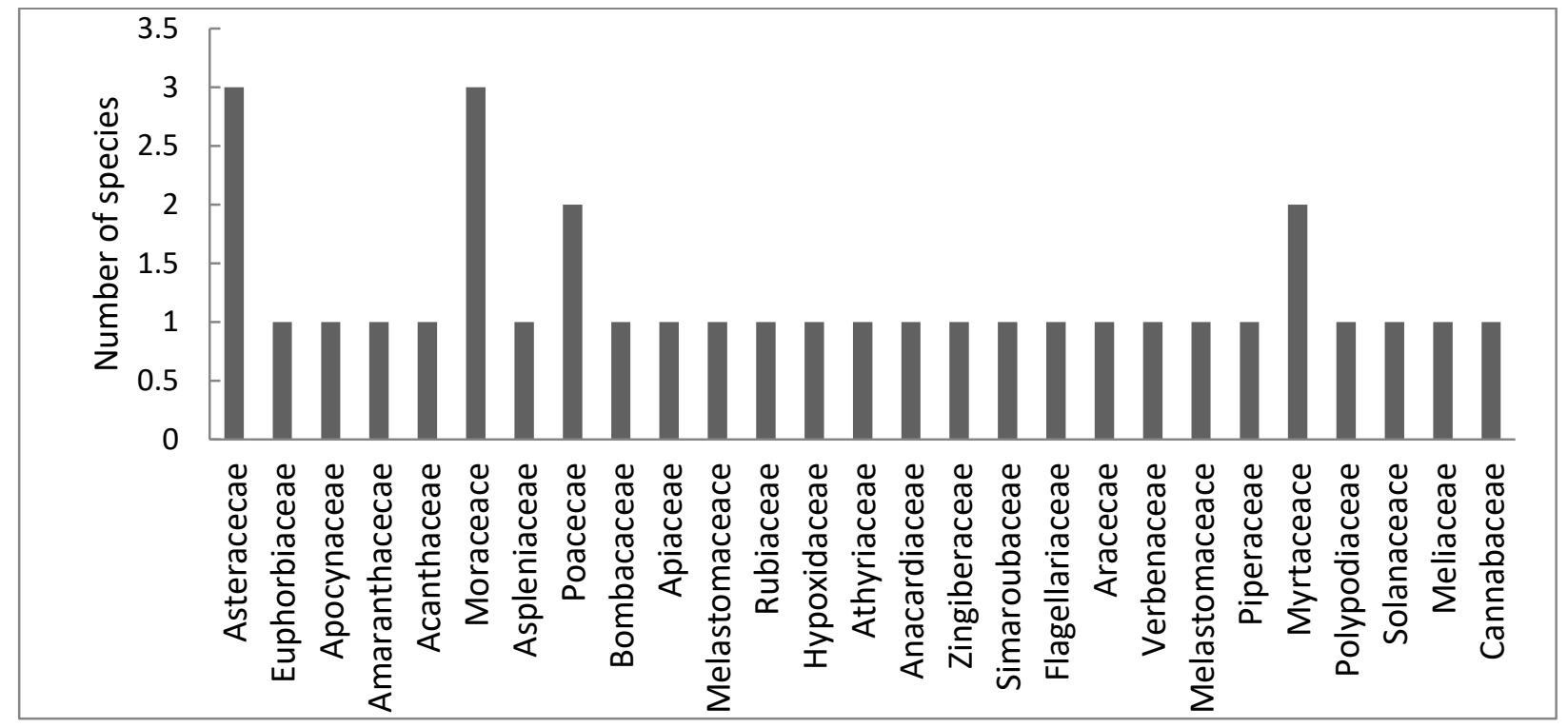

Figure 3. The family of the medicinal plants in the MADAPI Forest

The 1496 individual plants found representing 33 species and 27 families in MADAPI forest is less than the findings by Susatya [7] in Kerinci Seblat National Park that found 54 species and 16 families. Rahmawaty et al [15] found 34 medicinal plants in the agroforestry land in the buffer area of Gunung Leuser National Park. Giesen [16] identified 221 medicinal plants in Indonesia peat swamp forests. The quality of soil fertility in MADAPI Forest is quite good where the soil $\mathrm{pH}$ was not quite low (4.6 - 5.1). The small number of medicinal plants found is possibly due to the disruption of human activity in the area where the MADAPI Forest in recent years has been functioned as a tourist area. The number of open areas and land used for tourism purposes affects the number of medicinal plant availability.
The highest number species found was Diplazium esculentum, which belongs to Athyriaceae family. This species was found evenly in all four sections found in the A. moluccana area. This species easily spread and grows in various habitats, particularly in moist areas [17]. Jones et al [18]) reported that $D$. esculentum is an invasive terrestrial fern. This type is an edible fern that often used by people as vegetables [19]. As a medicinal plant, this species utilized to heal wounds and skin infections, dysentery, diarrhea, fever, antioxidants, and various other health benefits [20]. This species is a herb and grows in groups because of its propagation through spores and rhizomes (budding) which are mainly spread around the parent plant. 
Table 2. The abundance of the plants at the study sites

\begin{tabular}{|c|c|c|c|c|c|c|c|c|c|}
\hline \multirow[b]{2}{*}{ No } & \multirow[b]{2}{*}{ Species } & \multicolumn{2}{|c|}{ S. mahogani section } & \multicolumn{2}{|c|}{ A.dammara section } & \multicolumn{2}{|c|}{ P. merkusii section } & \multicolumn{2}{|c|}{ A. moluccana section } \\
\hline & & $\sum_{\substack{\text { individu } \\
\text { species }}}$ & $\begin{array}{c}\text { Abundance } \\
(\%)\end{array}$ & $\sum_{\substack{\text { individu } \\
\text { species }}}$ & $\begin{array}{c}\text { Abundance } \\
(\%)\end{array}$ & $\sum_{\begin{array}{c}\text { individu } \\
\text { species }\end{array}}$ & $\begin{array}{c}\text { Abundance } \\
(\%)\end{array}$ & $\underset{\substack{\text { individu } \\
\text { species }}}{\sum}$ & $\begin{array}{c}\text { Abundance } \\
(\%)\end{array}$ \\
\hline 1 & Ageratum conyzoides & - & & 20 & 19.02 & 30 & 9.59 & - & \\
\hline 2 & Aleurites moluccana & - & & - & 0.00 & - & 0.00 & 58 & 62.00 \\
\hline 3 & Alstonia scholaris & 1 & 0.001 & - & 0.00 & - & 0.00 & - & 0.00 \\
\hline 4 & Alternanthera sessilis & - & & 11 & 10.46 & 7 & 2.24 & - & 0.00 \\
\hline 5 & $\begin{array}{l}\text { Andrographis } \\
\text { paniculata }\end{array}$ & - & & - & 0.00 & 2 & 0.64 & - & 0.00 \\
\hline 6 & Artocarpus altilis & 3 & 0.03 & - & 0.00 & - & 0.00 & - & 0.00 \\
\hline 7 & Asplenium nidus & - & & - & 0.00 & 3 & 0.96 & - & 0.00 \\
\hline 8 & Bambusa multiplex & 4 & 0.15 & - & 0.00 & 18 & 0.23 & 1 & 0.02 \\
\hline 9 & Ceiba pentandra & - & & - & 0.00 & 3 & 0.01 & - & 0.00 \\
\hline 10 & Centella asiatica & - & & - & 0.00 & 64 & 20.46 & - & 0.00 \\
\hline 11 & Chromolaena odorata & - & & 20 & 19.02 & - & 0.00 & - & 0.00 \\
\hline 12 & Clidemia hirta & 3 & 0.12 & 63 & 2.40 & 168 & 2.15 & 13 & 0.23 \\
\hline 13 & Coffea sp. & - & & 20 & 0.76 & 63 & 0.81 & - & 0.00 \\
\hline 14 & Curculigo latifolia & - & & - & 0.00 & 4 & 1.28 & - & 0.00 \\
\hline 15 & Diplazium esculentum & 68 & 65.52 & 41 & 39.00 & 92 & 29.41 & 120 & 53.04 \\
\hline 16 & Dracontomelon dao & 20 & 0.19 & - & 0.00 & - & 0.00 & - & 0 \\
\hline 17 & $\begin{array}{l}\text { Erechtites } \\
\text { valerianifolius }\end{array}$ & 4 & 3.85 & 20 & 19.02 & 80 & 25.58 & 2 & 0.88 \\
\hline 18 & Etlingera elatior & - & & - & 0.00 & - & 0.00 & 98 & 43.32 \\
\hline 19 & Eurycoma longifolia & - & & - & 0.00 & 2 & 0.03 & - & 0.00 \\
\hline 20 & Ficus benjamina & - & & 1 & 0.01 & - & 0.00 & - & 0.00 \\
\hline 21 & Ficus septica Burm & - & & - & 0.00 & 4 & 0.01 & - & 0.00 \\
\hline 22 & Flagellaria indica & 13 & 0.50 & 8 & 0.30 & 20 & 0.26 & - & 0.00 \\
\hline 23 & Homalomena cordata & 5 & 4.82 & 4 & 3.80 & 10 & 3.20 & - & 0.00 \\
\hline 24 & Imperata cylindrica & 24 & 23.12 & 4 & 3.80 & 4 & 1.28 & - & 0.00 \\
\hline 25 & Lantana camara & - & & 30 & 1.14 & 3 & 0.04 & - & 0.00 \\
\hline 26 & $\begin{array}{l}\text { Melastoma } \\
\text { malabathricum }\end{array}$ & - & & - & 0.00 & 19 & 0.24 & - & 0.00 \\
\hline 27 & Piper betle & 1 & 0.04 & 4 & 0.15 & 14 & 0.18 & 2 & 0.04 \\
\hline 28 & Psidium guajava & - & & - & 0.00 & - & 0.00 & 1 & 0.00 \\
\hline 29 & Pyrrosia piloselloides & - & & - & 0.00 & 4 & 1.28 & 5 & 2.21 \\
\hline 30 & Solanum torvum & 1 & 0.04 & 3 & 0.11 & 9 & 0.12 & - & 0.00 \\
\hline 31 & Swietenia mahagoni & 167 & 61.00 & - & 0.00 & - & 0.00 & - & 0.00 \\
\hline 32 & Syzygium malaccensis & - & & - & 0.00 & - & 0.00 & 1 & 0.00 \\
\hline 33 & Trema orientalis & - & & - & 0.00 & 9 & 0.03 & - & 0 \\
\hline
\end{tabular}

The second most common species was Clidemia hirta which belongs to the family Melastomaceae. Le et al. [21] mentioned that this species is an invasive alien species originating from South America and has colonized tropical forests in Southeast Asia. Their study resulted that C. hirta commonly found along roads and trail that have a strong light. This C. hirta is most numerous in the P. merkusii section which has more openings due to cone-shaped pine canopy. C. hirta found in a small number in the more shaded forest floor of S. mahagoni and A. moluccana sections due to their closed canopy cover. C. hirta is a shrub and used as a wound healer. Rizki et al [22] reported that this species was one of the traditional medicinal plants by the indigenous people of West Pasaman, Indonesia.

The third most found species found was Chromolaena odorata which belongs to the family Asteraceae. This species was found only in A. dammara section. This species originated from America but is now commonly found in sub-Saharan Africa, Asia, and Oceania. C. odorata is a perennial shrub that is quite invasive so that it is considered a serious weed. However, this species has lots of health benefits and is commonly used by people in ethnopharmacological uses such as treatment fotr stomachache, coughs, and colds, toothache, malaria, 
diarrhea, skin infection [23]. Utami and Rahadian [14] reported that this species was one of the most prevalent medicinal plants found in Penggaron tourism forest of Central Java, Indonesia that benefit as anti-inflames and anti-diabetic. Rohman et al [24] reported that the Tengger tribe located in Bromo Tengger Semeru National Park, East Java utilized $C$. odorata as an insect repellent. Rahmawati et al [25] mentioned this species utilized by To Manui ethnic of Central Sulawesi, Indonesia as a flu healer.

All the medicinal plants identified were categorized as rare since the MADAPI Forest has functioned as a tourist area visited by lots of people. This condition leads to disrupt the growth, spread, and presence of plants including medicinal plants.

\subsection{Spatial Distribution}

Most of the medicinal species in MADAPI forest had VMR >1, indicating clumped distribution. A few species were distributed uniformly and randomly. The highest VMR was shown by E. elatior, followed by $D$. esculentum, A. moluccana, B. multiplex, S. mahagoni, L. camara, C. hirta, I. cylindrica, Coffea sp., and A. conyzoides (Table 3 and Figure 4).

Table 3. Spatial distribution the medicinal plant species at the study sites

\begin{tabular}{|c|c|c|c|c|}
\hline Species & Varian & Mean & Varian/Mean (VMR & Distribution Pattern \\
\hline A. conyzoides & 27.540 & 5.120 & 5.379 & Clumped \\
\hline A. moluccana & 130.500 & 11.600 & 11.250 & Clumped \\
\hline A. scholaris & 0.253 & 0.500 & 0.506 & Uniform \\
\hline A. sessilis & 8.880 & 3.000 & 2.960 & Clumped \\
\hline A. paniculata & 10.601 & 3.250 & 3.262 & Clumped \\
\hline A. altilis & 0.550 & 0.750 & 0.733 & Uniform \\
\hline A.nidus & 1.000 & 1.000 & 1.000 & Random \\
\hline B. multiplex & 84.400 & 9.000 & 9.378 & Clumped \\
\hline C. pentandra & 0.550 & 0.750 & 0.733 & Uniform \\
\hline C. asiatica & 24.300 & 5.300 & 4.585 & Clumped \\
\hline C. odorata & 15.500 & 4.500 & 3.444 & Clumped \\
\hline C. hirta & 66.143 & 7.484 & 8.838 & Clumped \\
\hline Coffea sp. & 34.700 & 5.900 & 5.881 & Clumped \\
\hline C. latifolia & 3.533 & 1.333 & 2.650 & Clumped \\
\hline D. esculentum & 123.039 & 9.171 & 13.416 & Clumped \\
\hline D. dao & 3.000 & 1.800 & 1.667 & Clumped \\
\hline E. valerianifolius & 16.000 & 4.000 & 4.000 & Clumped \\
\hline E. elatior & 372.000 & 19.600 & 18.980 & Clumped \\
\hline E. longifolia & 0.440 & 0.600 & 0.733 & Clumped \\
\hline F. benjamina & 0.200 & 0.500 & 0.400 & Uniform \\
\hline F. septica & 0.980 & 1.000 & 0.980 & Uniform \\
\hline F. indica & 3.300 & 1.900 & 1.737 & Clumped \\
\hline H. cordata & 12.000 & 3.750 & 3.200 & Clumped \\
\hline I. cylindrica & 41.960 & 6.400 & 6.556 & Clumped \\
\hline L. camara & 73.487 & 8.250 & 8.908 & Clumped \\
\hline M. malabathricum & 21.200 & 4.700 & 4.511 & Clumped \\
\hline P. betle & 23.260 & 5.000 & 4.652 & Clumped \\
\hline P. guajava & 0.253 & 0.500 & 0.506 & Uniform \\
\hline P. piloselloides & 5.032 & 2.250 & 2.236 & Clumped \\
\hline S. torvum & 3.300 & 2.700 & 1.222 & Clumped \\
\hline S. mahagoni & 99.200 & 10.600 & 9.358 & Clumped \\
\hline S. malaccensis & 0.253 & 0.500 & 0.506 & Uniform \\
\hline T. orientalis & 8.900 & 3.000 & 2.967 & Clumped \\
\hline
\end{tabular}




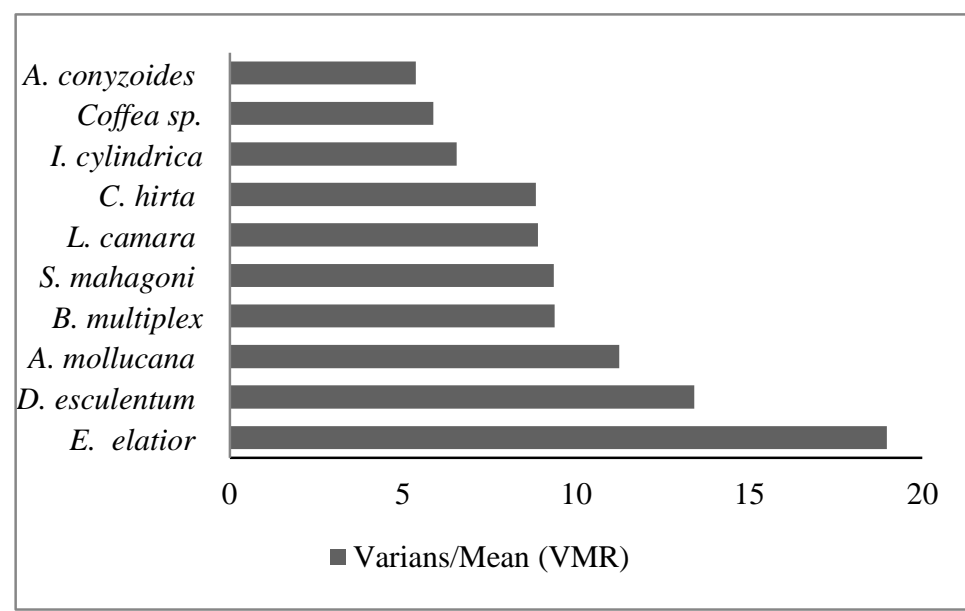

Figure 4. The top ten of the highest VMR of the medicinal plants

Plant distribution patterns generally consist of three distribution patterns namely random, uniform, and clumped. Generally, most plant species are clumped in an area. Genetic factors of the species may cause a different distribution pattern [26]. However, the distribution pattern is also affected by interactions between individuals in the ecosystem. The effect of environmental and competition factors may hamper the species to spread far away from the parent plant. Amaral et al [27] mentioned that the species which cannot survive under a specific environment leads to growth in a clump distribution pattern. Susilowati et al [28] reported that Eurycoma longifolia seedling was distributed in groups and close to the mother plants. Lestari and Asih [29] mentioned that seed spreading agents may affect the distribution of plants, so that clustered plants usually do not have agents to spread the seeds. According to Russo and Augspurger [30] some factors such as seed predators, seed spreading agents and seedling pathogens may affect plant distribution patterns. This is confirmed by Okuda et al [31] stated that the number of seeds, seedling predators, and low species mortality rates also cause clump distribution patterns for plants. Human disturbances may affect the effectiveness of plant distribution patterns. A safe location and far from human accessibility and disturbance lead to plants to grow in a clumped pattern.

\section{CONCLUSION}

There were 33 species of medicinal plants were found, representing 27 families. The most dominant families found in the sites were Asteraceae and Moraceae Mostly the plants were herbs. All of medicinal plant species were categorized as rare with clumped distribution; only a few species were spread randomly or uniformly.

\section{ACKNOWLEDGMENTS}

This research was supported by a grant from the Center of Research and Community Service, University of Bengkulu. The authors would like to thank for the funding and assisting the research administration. We thank the students at the Department of Forestry, Faculty of Agriculture of the University of Bengkulu who participated in data collection.

\section{REFERENCES}

[1] E. Purwanto. 2015. The strategy of anti-encroachment in Sumatra's Tropical Forest Heritage Area (TRHS): Towards a New Paradigm. Tropenbos International Indonesia Program and UNESCO Jakarta

[2] A. Novra and M. Farhan 2009. Characteristics of the household's socio-economic of the buffer village of Kerinci Seblat National Park. Research Journal of University of Jambi, Humanities Series 11 (1): 11-20

[3] Mongabay.

2019. https://www.mongabay.co.id/2019/05/03/ forestdepleted-herbs-medicine-difficult /

[4] Ministry of Forestry. 2015. Indonesian Government Regulation Number 108: Amendments to Government Regulation Number 28 of 2011 concerning Management of Nature Sanctuary and Nature Conservation Areas

[5] I. Fahrurozi. 2014. The diversity of medicinal plants in the Gunung Gede Pangrango National Park and the Cibodas Botanical Garden's Fragmented Forest and its utilization by the community. Thesis at Department of Biology, Faculty of Science and Technology, Syarif Hidayatullah State Islamic University.

[6] E.S. Zulnely, Sumadiwangsa, E. Dahlian, U. Kulsum. 2004. Active components of 20 types medicinal plants in Mount Halimun National Park. Research Journal of Forest Products 22 (1): 43-50

[7] A. Susatya. 2010. The preliminary study of the medicinal plant from Kerinci Seblat National Park as anticancer and anti-HIV. Journal of Indonesian Medicinal Plants 3(1):47-54

[8] M. Mahajan and S. Fatima. 2017. Frequency, abundance, and density of plant species by list count quadrat method, International Journal of Multidisciplinary Research 3 (7): 1-8

[9] J.A. Ludwig and J.F. Reynolds. 1988. Statistical Ecology: A Primer on Methods and Computing. WileyInterscience Pub. New York.

[10] S. Kayani, M. Ahmad, S. Sultana, Z.K. Shinwari, M. Zafar G. Yaseen, M. Hussain, T. Bibi. 2015. Ethnobotany of medicinal plants among the communities of Alpine and Sub-alpine regions of Pakistan. Journal of Ethnopharmacology 164: 186-202 
[11] M.S. Nahdi, INA Martiwi, DC Arsyah. 2016. The ethnobotany of medicinal plants in supporting the family health in Turgo, Yogyakarta, Indonesia. Biodiversitas 17: 900-906

[12] Syamsiah, SF Hiola, A Mu'nisa, O Jumadi. 2016. Study on medicinal plants used by the ethnic Mamuju in West Sulawesi, Indonesia. Journal of Tropical Crop Science 3(2): 42-48

[13] R Susanti, EAM Zuhud. 2019. Traditional ecological knowledge and biodiversity conservation: the medicinal plants of the Dayak Krayan people in Kayan Mentarang National Park, Indonesia. Biodiversitas 20: 2764-2779

[14] Utami S, Rahadian R. 2018. Diversity and abundance of medicinal plants in Penggaron tourism forest of Central Java, Indonesia. IOP Conf. Series: Journal of Physics: Conf. Series 012175.

[15] Rahmawaty, R. Amalia, R. Batubara, A. Rauf. 2019. Medicinal plant inventory at the agroforestry land in buffer area of Gunung Leuser National Park. The 14th Pacific Rim Bio-Based Composites Symposium IOP Conf. Series: Materials Science and Engineering 593 (2019) 012023.

[16] W. Giesen. 2015. Utilizing non-timber forest products to conserve Indonesia's peat swamp forests and reduce carbon emissions. Journal of Indonesian Natural History 3 (2) : 17-26

[17] GN Archana, S Pradeesh, DM Chinmayee, I Mini, TS Swapna. 2012. Diplazium esculentum: A wild nutrientrich leafy vegetable from Western Gaths. Prospect in Bioscience: Addressing the issues: 293-301

[18] EJ Jones, T Kraaij, C Guerbois , D Moodley. 2020. An assessment of the invasion status of terrestrial alien ferns (Polypodiophyta) in South Africa. South African Journal of Botany 131: 64-73

[19] R Della, C Wijaya, Hanny, H. Yasuyuki, D,G unawan H,Akira, W. Toshihiro, K Kanta, NY Asi. 2017. Concentration of some trace elements in two wild edible ferns, Diplazium esculentum and Stenochlaena palutris, inhabiting tropical peatlands under different environments in Central Kalimantan. Eurasian J. For. Res. 20: 11-20

[20] EE,Essien, $\mathrm{R}$ Ascrizzi, G Flamini. 2019. Characterization of volatile compounds of Diplazium esculentum. Chemistry of Natural Compounds 55 (5): 958-959

[21] C Le, K,Fukumori, T. Hosaka, S. Numata, M. Hashim T. Kosaki. 2018. The distribution of an invasive species, Clidemia hirta along roads and trails in Endau
Rompin National Park, Malaysia. Tropical Conservation Science 11: 1-9

[22] R. Rizki, Nursyahra, O. Fernando. 2019. Study of weeds as traditional medicinal plants used by indigenous people of West Pasaman, Indonesia. Journal of Tropical Horticulture 2 (2) : 81-85.

[23] AG. Omokhua, LJ. McGaw , JF Finnie, J. Van Staden. 2016. Chromolaena odorata (L.) R.M. King \& H. Rob. (Asteraceae) in sub-Saharan Africa: A synthesis and review of its medicinal potential. Journal of Ethnopharmacology 183:112-122

[24] F Rohman, Y Juma, Sulisetijono, DH Utomo, Purwanto, SR Lestari, SN Arifah, WE Putra. 2019. Plants diversity as medicinal plants by the Tengger Tribe, Bromo Tengger Semeru National Park, East Java, Indonesia. Eurasia J Biosci 13: 2293-2298

[25] N Rahmawati, FI Mustofa, S Haryanti. 2020. Diversity of medicinal plants utilized by To Manui ethnic of Central Sulawesi, Indonesia. Biodiversitas 21 (1): 375392

[26] JL Hamrick, DW Trapnell. 2011. Using population genetic analyses to understand seed dispersal pattern. Acta Oecologica 37: 641-649

[27] MK Amaral, SP Netto, C Lignau, AF Filho. 2015. Evaluation of the Morishita index for determination of the spatial distribution of species in a fragment of Araucaria forest. Applied Ecology and Environmental Research 13:361-372

[28] A. Susilowati, HH Rachmat, D Elfiati, MH Hasibuan. 2019. The composition and diversity of plant species in pasak bumi's (Eurycoma longifolia) habitat in Batang Lubu Sutam forest, North Sumatra, Indonesia. Biodiversitas 20 (2): 413-418

[29] D. Lestari, PS Asih. 2017. Population structure, distribution pattern and microhabitat characteristics of Aglaonema simplex in Pasatan Protected Forest, Jembrana, Bali, Indonesia. Biodiversitas 18 (4): 1663 1668

[30] SE. Russo, CK. Augspurger. 2004. Aggregated seed dispersal by spider monkeys limits recruitment to clumped patterns in Virola calophylla. Ecol Lett 7: 1058-1067.

[31] T. Okuda, N. Kachi, SK. Yap, N. Manokaran. 1997. Tree distribution pattern and fate of juveniles in a lowland tropical rain forest-implication for regeneration and maintenance of species diversity. Plant Ecol 131: 155-171 